\title{
LABORATORY MODELING OF KARST PHENOMENA AND THEIR ROCK RELIEF ON PLASTER, SUBSOIL KARREN, RAIN FLUTES KARREN AND CAVES
}

\author{
LABORATORIJSKO MODELIRANJE KRAŠKIH POJAVOV IN \\ NJIHOVEGA SKALNEGA RELIEFA NA MAVCU: PODTALNE \\ ŠKRAPLJE, DEŽNI ŽLEBIČI IN JAME
}

\author{
Tadej SLABE ${ }^{1,2}$, Asami HADA ${ }^{3}$ \& Martin KNEZ ${ }^{1,2}$
}

\begin{abstract}
UDC 911.2:551.435.8

Tadej Slabe, Asami Hada \& Martin Knez: Laboratory modeling of karst phenomena and their rock relief on plaster: subsoil karren, rain flutes karren and caves

The study of the formation and development of karst phenomena and their rock relief using laboratory plaster modeling has again proven useful and informative. We continued the study of subsoil karren that forms under tight, poorly permeable contact with soil and of rain flutes formed by water at various temperatures. We determined the pattern of the reshaping of plaster tubes that are wider at the flow inlet than at the outlet end. The results are a significant contribution to explaining the formation of high ceiling niches and pockets in karst caves. The third experiment was carried out in phreatic conditions where water in a flume was forced to flow between layers of different composition. During the experiment, we observed the typical development of channels between pure plaster layers (uniform limestone beds), between plaster layers with added Portland cement reinforced fragments (breccia beds), siporex (slowly dissolving beds) and between three different layer types.

Key words: laboratory modeling, karst, rock relief, subsoil karren, rain flutes, caves.
\end{abstract}

\begin{abstract}
Izvleček
UDK 911.2:551.435.8

Tadej Slabe, Asami Hada \& Martin Knez: Laboratorijsko modeliranje kraških pojavov in njihovega skalnega reliefa na mavcu: podtalne škraplje, dežni žlebiči in jame

Proučevanje oblikovanja in razvoja kraških pojavov in njihovega skalnega reliefa $\mathrm{z}$ laboratorijskim modeliranjem $\mathrm{z}$ mavcem se je spet izkazalo kot koristno in povedno. Nadaljevali smo s proučevanjem podtalnih škrapelj, ki se oblikujejo pod tesnim, slabo prepustnim stikom s prstjo in dežnih žlebičev, ki se oblikujejo $\mathrm{z}$ vodo različnih temperatur. Razbrali smo način oblikovanja mavčnih cevi, ki so širše na pritočni kot odtočni strani. Izsledki so pomemben prispevek k razlagi oblikovanja visokih stropnih niš in kotlic v kraških jamah. Tretji poizkus smo izvedli v freatičnih pogojih, ko se je voda pretakala med plastmi različne sestave. Opazovali smo značilen razvoj kanalov med ploščami čistega mavca (apnenčasta plast), med ploščami mavca $\mathrm{z}$ dodanimi in s cementom učvrščenimi počasneje topnimi klasti (breča), siporeksom (slabo topna kamnina) in med tremi različnimi ploščami.

Ključne besede: laboratorijsko modeliranje, kras, skalni relief, podtalne škraplje, žlebiči, jame.
\end{abstract}

\footnotetext{
${ }^{1}$ Karst Research Institute, Research Centre of the Slovenian Academy of Sciences and Arts, Titov trg 2, SI-6230 Postojna, Slovenia and UNESCO Chair on Karst Education, University of Nova Gorica, Glavni trg 8, SI-5271 Vipava, Slovenia, e-mails: knez@zrc-sazu.si, slabe@zrc-sazu.si

${ }^{2}$ Yunnan University International Joint Research Center for Karstology, Xueyun rd. 5, CN-650223, Kunming, China, e-mails: knez@zrc-sazu.si, slabe@zrc-sazu.si

${ }^{3}$ Nihon University, College of Commerce, 5-2-1 Kinuta, Setagaya-ku, Tokyo, Japan, e-mail: hada.asami@nihon-u.ac.jp

Received/Prejeto: 13.07.2016
} 


\section{INTRODUCTION}

The modeling of karst phenomena and their rock forms and relief in plaster exposed to different factors in a variety of conditions has often proved useful. The limitations and particularities of plaster modeling often originate in the fact that in most cases the models are smaller than the original phenomena in nature and that more plaster dissolves (more than $2 \mathrm{~g}$ of plaster dissolves per $100 \mathrm{~g}$ of water at $20^{\circ} \mathrm{C}$ ). The consequence of the latter is that the forms on plaster are typically smaller than those on limestone and their development cycle is much faster. According to our experience, however, they provide a very useful comparison. Modeling offers various possibilities for the continuous monitoring of the origin and development of rock forms. While the modeling of a plaster block exposed to a flow of water or to rain can be monitored continuously, an experiment in the formation of subsoil karren must be repeatedly interrupted and renewed and the formation of rock relief in plaster tubes exposed to a water current can only be monitored using special instruments.

We continue with the studying the formation of subsoil karren and subsoil rock teeth (Slabe 2005, 2009; Slabe \& Liu 2009), we tried to make clear the effects of water temperature on the formation processes of rain flutes (Ginés 2009; Slabe 2009), and continue with research of the development of caves by exposing tubes of different diameters and a plaster block composed of different layers to a flow of water. Models are different, so the methods are presented in the beginning of each.

\section{PREVIOUS PLASTER MODELING EXPERIMENTS DESCRIBED IN THE LITERATURE}

Experiments in modeling have deepened our knowledge about cave rock forms.

Rudnicki (1960), Curl (1966), Goodchild \& Ford (1971), and Allen (1972) studied scallops with plaster models. Curl (1966) established beyond dispute that the length of scallops depends on the speed of the water constantly flowing over the rock; the size and shape of scallops is also influenced by the size of the passage whose walls contain the scallops, the density and viscosity of the water, ions diffusion, and the properties of the rock where the scallops form. Goodchild \& Ford (1971) studied the relationship between the size of scallops and the hydraulic conditions. Allen (1972) used experiments with plaster channels to demonstrate that scallops can form on rock whose component parts are large enough for the development of independent vortexes. The presence of non-homogeneous elements influences the distribution of scallops and a single non-homogeneous element can trigger the formation of scallop-like features.

Quinif (1973) used a model to study the formation of ceiling pockets. He immersed a fissured block in water and poured $\mathrm{HCl}$ through a fissure. A ceiling pocket formed at its bottom.

Lauritzen (1981) studied the paragenetic transformation of a cave ceiling above fine-grained sediment using plaster modeling experiments.

Ewers $(1966,1972,1982)$ used salt models to study bedding-plane anastomoses.

Experimental research (Slabe 1995a, b) on abovesediment ceiling channels and anastomoses in caves, below-sediment flutes, different types of scallops and the impact of rock and hydraulic conditions on their size and shape, and ceiling pockets formed due to the percolation of water through fissures contributed considerably to explaining their origin under different conditions and the diverse shaping of karst caves.

Many experiments have been conducted on the formation of karst surfaces and the rock forms on them.

Pluhar and Ford (1970) studied the formation of flutes by using hydrochloric acid on a dolomite block.

Glew and Ford (1980) studied flutes and rillenkarren in experiments exposing plaster surfaces inclined from $22.5^{\circ}$ to $60^{\circ}$ to artificial rain. They established that flutes form in places where a thin layer of water flowing across an inclined surface does not block rain drops from direct contact with the rock. Under a thicker layer of water, however, the surface of the rock becomes smooth. The length of flutes is related to the inclination of the rock surface.

Dzulynski et al. (1988) used modeling to study the formation of karren by exposing a fissured block of plaster to artificial rain. They studied karren formed by rainwater as well as subsoil karren. They were interested in how the plaster is dissected by channels that form along fissures, how protrusions form between them, and how the level of water surrounding them affects their development. They determined that the amount of rain affects the speed at which the plaster dissolves but not the shape of the artificial karren. The plaster covered with sand displayed karren similar to that on bare plaster and only pil- 
lars were less sharply dissected. On the walls of a small model of uncovered karren it was possible to distinguish vertical channels at the ends of fissures (lapies wells, karrenröhren) and funnel-shaped recesses at their tops with channels below them.

Tućan (1911) exposed limestone and dolomite blocks to hydrochloric and nitric acid and established that their surfaces resembled those in nature, with characteristic differences, of course, between the limestone and dolomite. Mowat (1962) used plates of various shapes to confirm the findings of Lange (1959) that during the dissolving process concave areas become rounded and convex areas are sharpened. Trudgill (1985) described the smoothing of rock surfaces due to their exposure to acidic water. He proved his findings with laboratory tests using acids and scanning rock surface with an electron microscope.

Mathematical and computer modeling opens up new possibilities (Perne \& Gabrovšek 2009). Slabe (2009) researched rock relief of karren.

\section{CONTINUATION OF TEST MODELING OF SUBSOIL KARREN FORMATION}

The previous results have already been presented in detail (Slabe 2005, 2009); here we add new findings acquired with new models.

For the earlier experiments (Slabe 2005), a plaster block was sliced into pillars with square cross sections and sides measuring $6 \mathrm{~cm}$ and a height of $30 \mathrm{~cm}$ (Fig. 1). The pillars were placed closely side by side in a large bucket and covered with soil. Holes were drilled in the bottom of the bucket and lastly the bucket was filled with water. The water began to percolate through the soil and run out through the holes at the bottom of the bucket.

The upper two thirds of the pillar walls were corroded by tiny features, the traces of the water percolating through the sediment and its flow along the contact between plaster and sediment.
The entire surface of the upper sections of the pillars was finely corroded by small cups (Fig. 2) up to $2 \mathrm{~cm}$ in diameter, although most are smaller. They are the consequence of water percolating constantly through the most permeable layer of soil.

The larger cups (Fig. 2), typically found in the middle sections of the pillars, display relatively smooth surfaces. On rock, of course on a much larger scale, this type of hollow is called a "subsoil scallop" (Slabe 2005).

Along the fissures or other weak spots in the rock, individual deeper semicircular or channel-shaped hollows often occur that in time can develop into subsoil tubes (Fig. 2).

Channels with diameters ranging from one to three centimeters formed on the walls of the lower sections of

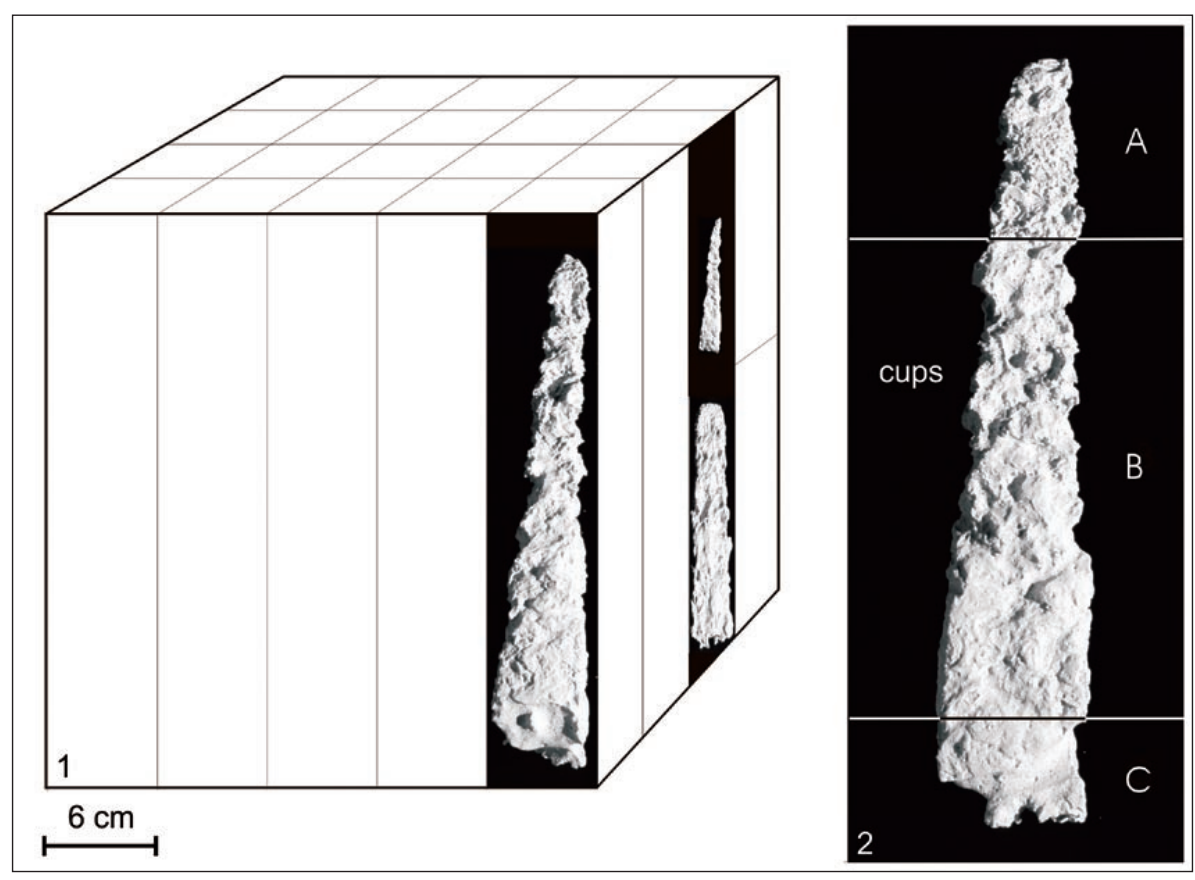

Figs. 1, 2: Pillars of plaster stone forest. 


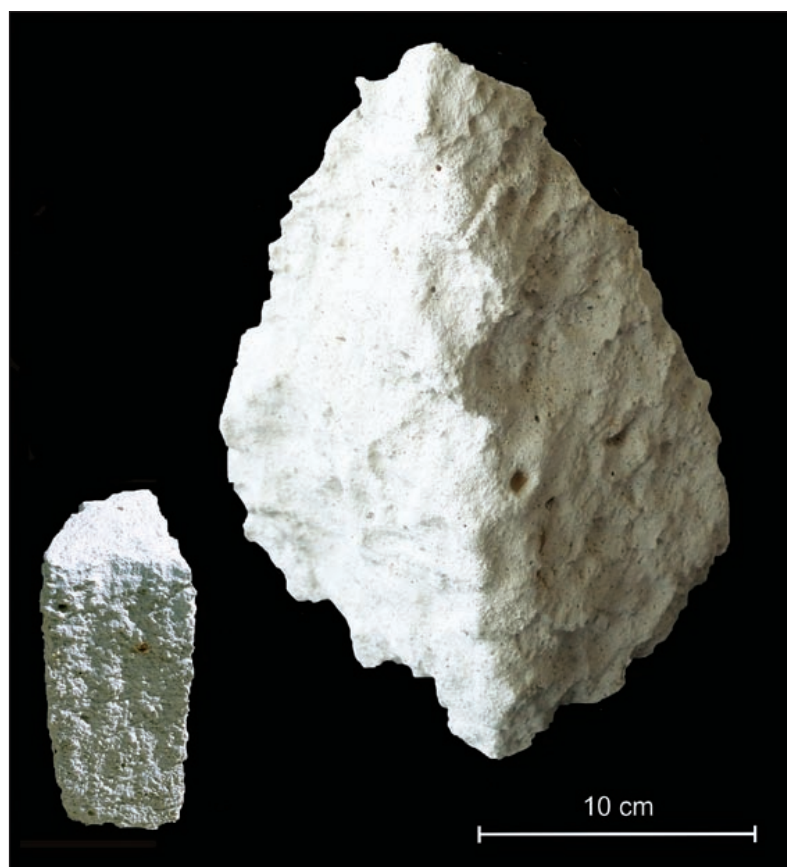

Fig. 3: Development of subsoil tooth on plaster of Paris.

the columns (Fig. 2 B) The locally saturated zone, which developed because the quantity of water flowing along the contact was greater than the quantity that could flow out of the perforated bottom of the bucket, reached as far as the upper level of the channels. This border is often marked by notches.

On the lower surfaces of the pillars, even those cut in half horizontally, there are distinct networks of abovesediment anastomoses (Fig. 2).

The angularity and square cross sections of the pillars were preserved throughout their entire height. The characteristically pointed shape of the upper sections of the pillars is the consequence of the dispersed percolation of water through the soil that covered the plaster.

In the latest experiment, larger plaster pillars (the largest was $20 \mathrm{~cm}$ long and $16 \mathrm{~cm}$ wide, smaller ones $12 \mathrm{~cm}$ long and $8 \mathrm{~cm}$ wide; all were $30 \mathrm{~cm}$ in height; Fig. 3) were covered with a finer fine-grained clay less permeable for water. Thus the contact between the clay and the rock was also less permeable. Subsoil shafts were the first to form between the pillars. As parts of the shafts, vertical subsoil channels with funnel-like mouths at their tops (Fig. $3 \mathrm{~A}$ ) formed on the upper sections of the pillar walls. The diameter of these features reached $3 \mathrm{~cm}$. Along the less permeable contact between the plaster and the clay the water seeks the most permeable routes and merges together in flows. This was confirmed by bubbles on the surface of the water that revealed a number of distinct ponors. A special type of channel such as described in the experiment above formed on the lower section of the pillars in the locally
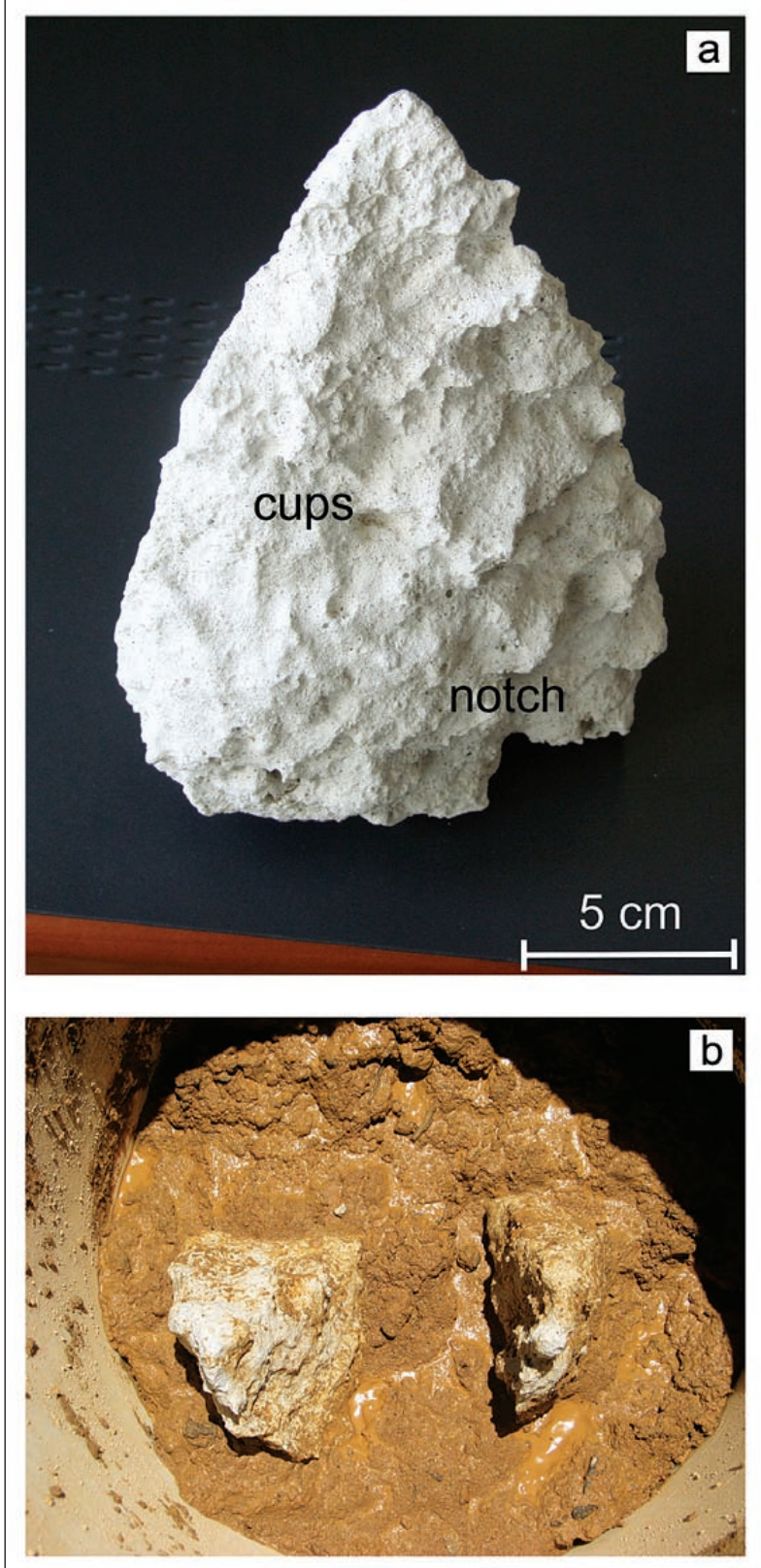

Fig. 4: a. relief of subsoil tooth on plaster, $b$. shaping of plaster teeth under the soil.

saturated zone. Anastomoses formed on the lower surface of the pillars (Fig. 4a).

The tops of the pillars gradually sharpened and approached the shape of a point (Fig. $4 \mathrm{~b}$ ). The process was frequently interrupted in order to examine all the phases in the development of subsoil karren.

When the experiment ended after 800 hours, the two larger pillars were $20 \mathrm{~cm}$ tall, the wider being $10 \mathrm{~cm}$ long and the narrower $5 \mathrm{~cm}$. All that remained of the smaller pillars were two $5 \mathrm{~cm}$ tall and up to $1.5 \mathrm{~cm}$ wide pieces of plaster. 
The pillars are completely pointed, which of course is most visible in the larger two pillars, especially the widest (Figs. 3, 4a, 4b). The sharp side edges were preserved.

The rock relief gradually began to resemble that in the first experiment, particularly on individual surfaces. The surface of the pillars, however, tends to be smoother as a rule. New characteristics are preserved, specifically the dissection by more or less vertical and, due to the varying permeability of the contact between the plaster and clay, more or less meandering subsoil channels (Figs. 3, 4a). Higher on the pillar walls than in the first experiments there are horizontal or variously inclined wall notches reflecting the more complete filling of fissures and the tighter contact between plaster and clay and consequently the lower permeability of the model (Figs. 3, 4a). In many places the surface of the plaster was weathered, indicating that the soluble material had not been simultaneously removed everywhere.
The experiments confirm the knowledge acquired in the field (Slabe \& Liu 2009). Of course, it is necessary to consider the fact that plaster dissolves rapidly and its surface is consequently more finely dissected. Water percolates downward through soil and various fine-grained sediments and flows through fissured rock. The peaks of rock become sharper, points or blades begin to take shape, and fissures grow into cracks. Water then fills them with sediment beside which forms characteristic subsoil rock relief. Along the permeable contact between rock and sediment, water creeps over the entire surface enabling the formation of subsoil scallops. Along less permeable contacts, however, water consolidates to find paths, carving subsoil shafts and channels. The surface between them can become weathered. A unique rock relief forms in locally saturated zones. The subsoil karren in the lower parts of the Dolenjska karst in Slovenia that periodically are completely flooded by groundwater are a typical example (Knez et al. 2004).

\section{MODELING OF PLASTER BLOCKS UNDER AN ARTIFICIAL RAINFALL OF DIFFERENT TEMPERATURE - INNITIAL STAGES OF RAIN FLUTES DEVELOPMENT}

In order to clarify the formation processes of rain flutes (rillenkarren), a laboratory experiment was carried out (Hada 2008, 2010). Two blocks made from plaster of Paris having a $45^{\circ}$ inclined surface with an area of $120 \mathrm{~mm}$ long by $80 \mathrm{~mm}$ wide were placed under a vertical spray for 1,000 hours. The temperatures of tap water sprayed were $45 \pm 5{ }^{\circ} \mathrm{C}$ and $24 \pm 3{ }^{\circ} \mathrm{C}$. The changing form of the rain flutes was measured using photographs. The width $(\mathrm{W}, \mathrm{mm})$ and depth $(\mathrm{D}, \mathrm{mm})$ were measured from the top of the $45^{\circ}$ inclined surface at the $1 \mathrm{~cm}, 2.5 \mathrm{~cm}, 4 \mathrm{~cm}$, $6 \mathrm{~cm}, 8 \mathrm{~cm}$, and $10 \mathrm{~cm}$ lower points on the surface every 50 hours.

In both $45 \pm 5{ }^{\circ} \mathrm{C}$ and $24 \pm 3{ }^{\circ} \mathrm{C}$ water temperatures, the rain flutes lengths (Figs. 5, 6) increased downward from the top of the $45^{\circ}$ slopes in accordance with the time. At the same time, the widths became greater and depths became deeper (Figs. 7, 8). It is evident that the cross-sections of the rain flutes at the top of the sloped surface became larger than their initial form (Fig. 9), and the widths and depths of the rain flutes in the lower part were larger than in the upper part.
The original sloped surface was eroded and the changes to the rain flutes forms were observed. Rain flutes lengths in the case of $45 \pm 5^{\circ} \mathrm{C}$ water temperature became longer and grew more rapidly downwards than under the $24 \pm 3{ }^{\circ} \mathrm{C}$ water temperature conditions. In the case of $45 \pm 5^{\circ} \mathrm{C}$ water temperature, flutes widths expanded rapidly from the start up to 100 hours, and their cross-sections acquired a deep shape from the start up to 200 hours (Figs. 7, 8). In case of $24 \pm 3{ }^{\circ} \mathrm{C}$ water temperature, widths expanded slowly from the start up to 350 hours and then the depths of rain flutes increased rapidly up to 550 hours when they became stable (Figs. 7,8). Finally, the volume of plaster removed from each block was estimated and compared using the rain flutes profiles. The amount removed was significantly larger under $45 \pm 5{ }^{\circ} \mathrm{C}$ conditions. 


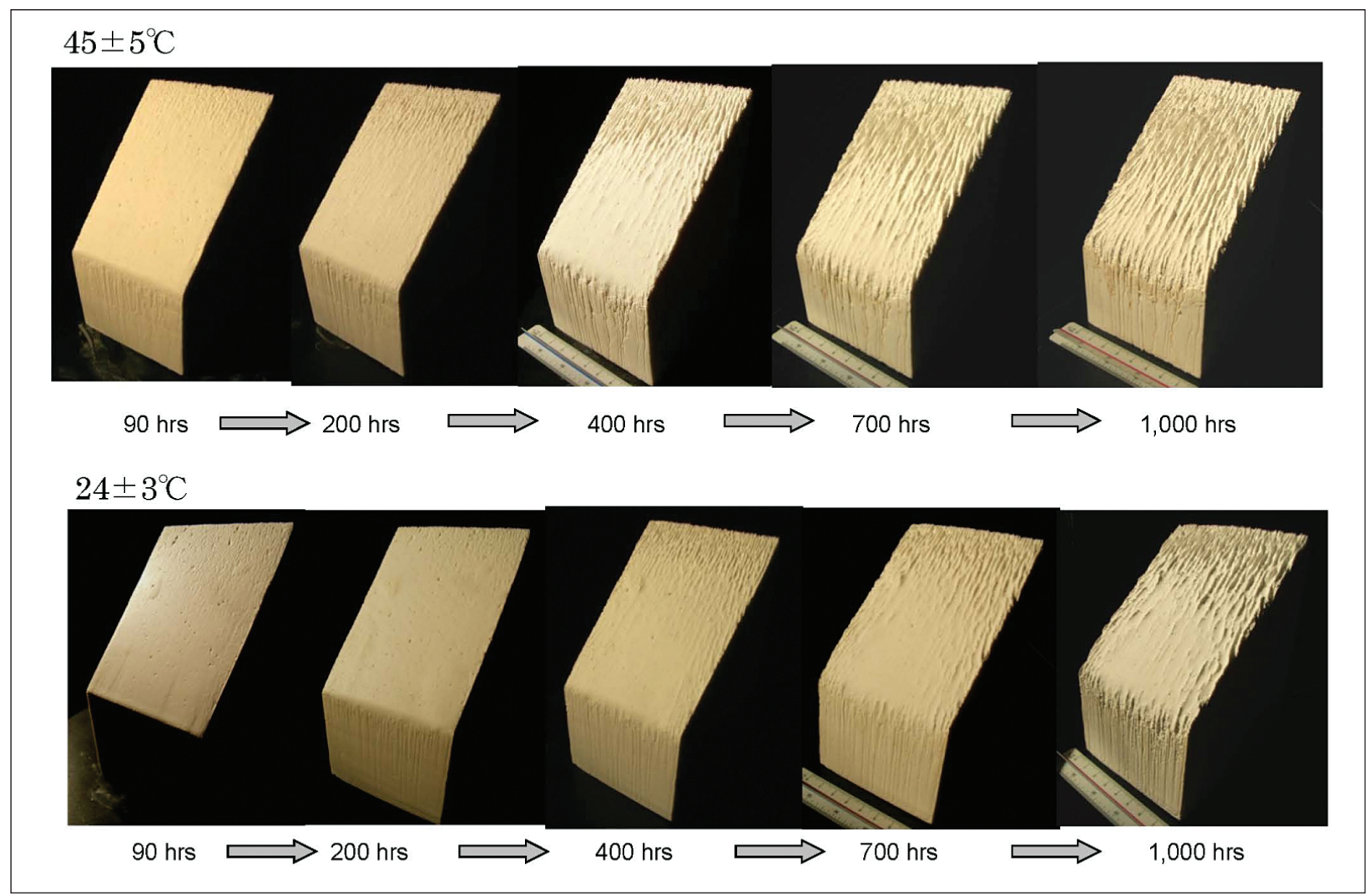

Fig. 5: Development of rain flutes on plaster of Paris blocks.

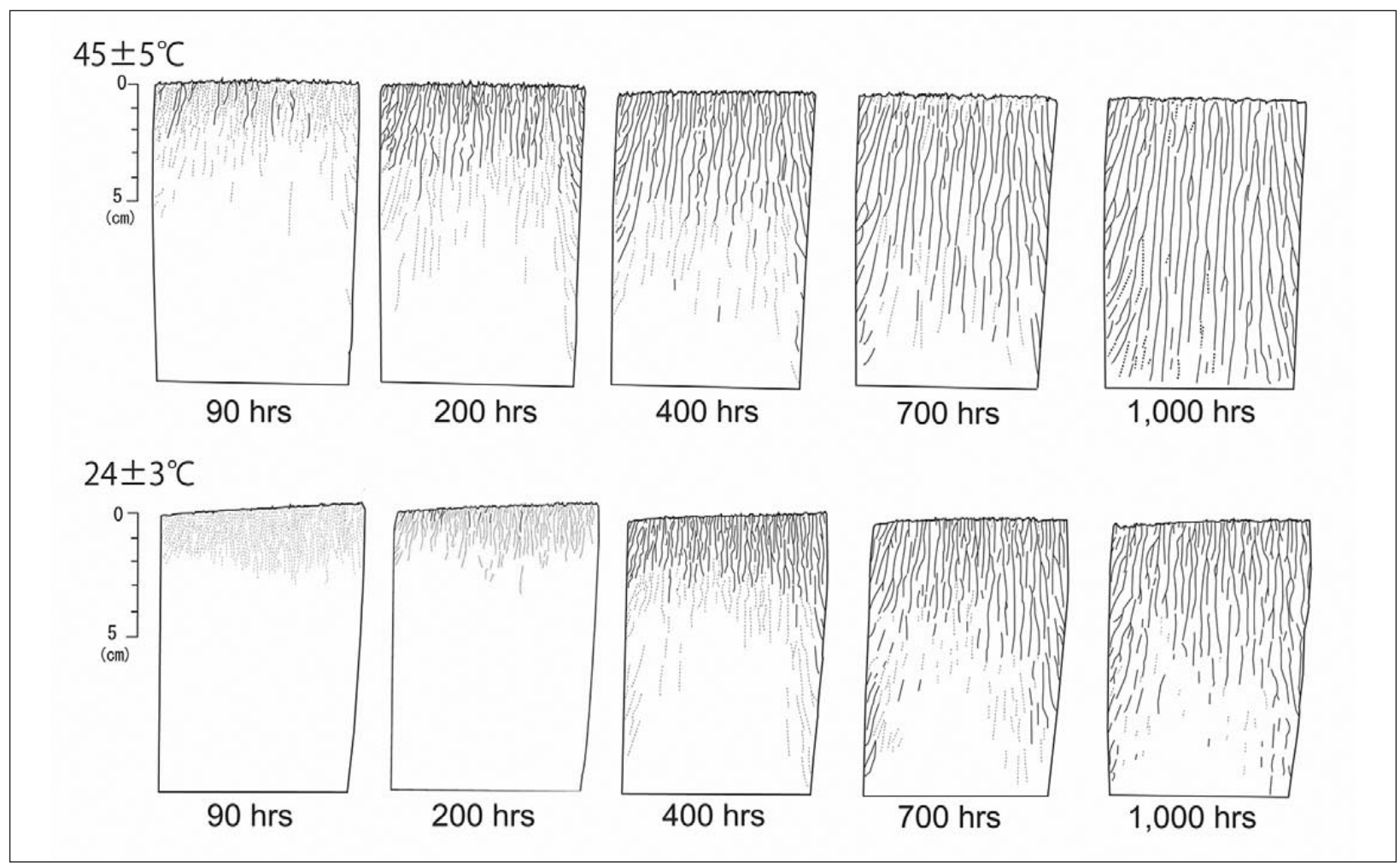

Fig. 6: Distribution of rain flutes on plaster blocks. 

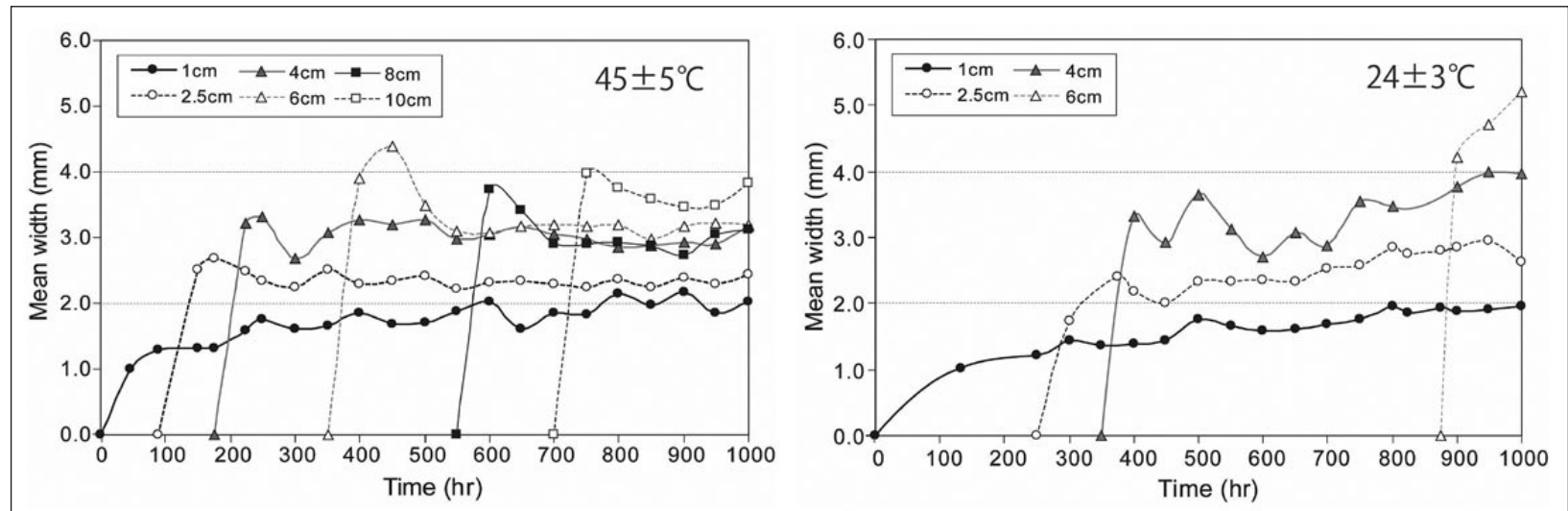

Fig. 7: Relationship between width of rain flutes and elapsed time.
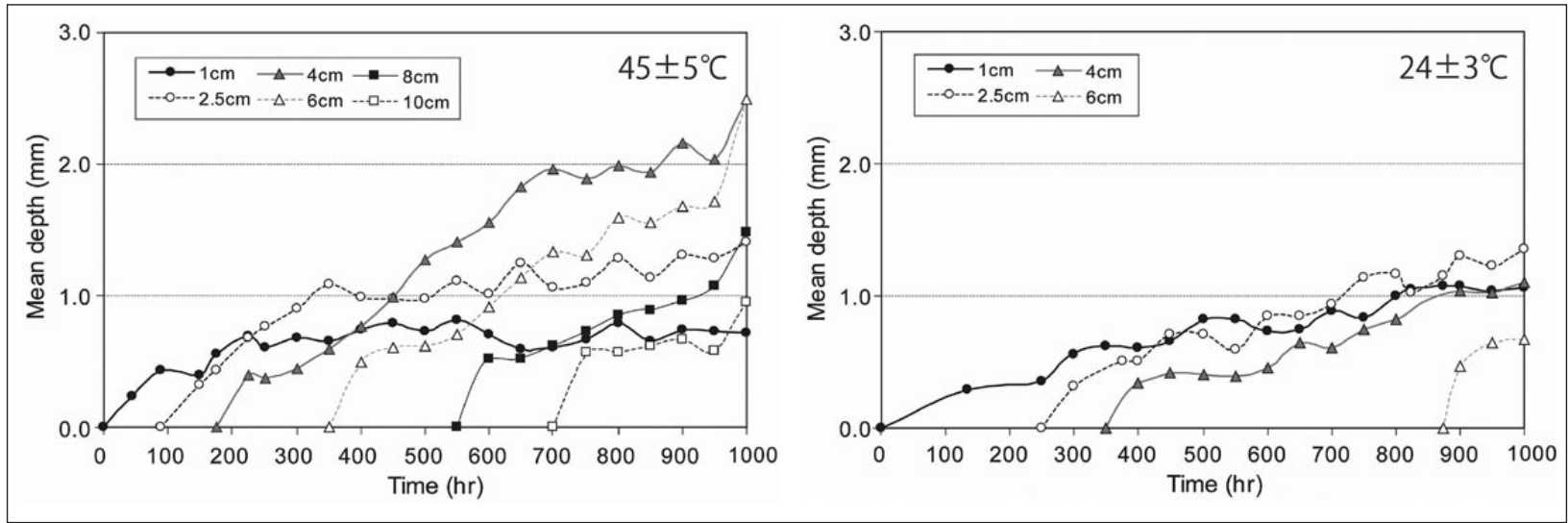

Fig. 8: Relationship between depth of rain flutes and elapsed time.

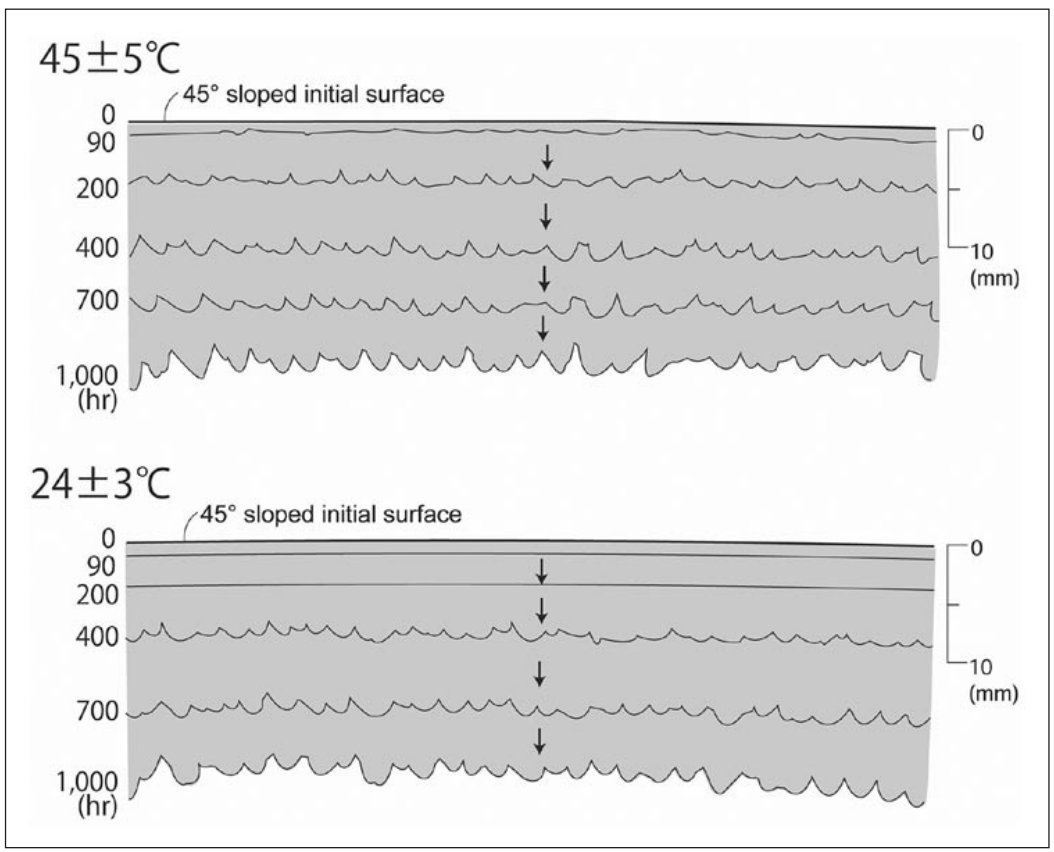

Fig. 9: Cross-sectional profiles of plaster blocks. 


\section{MODELING OF PLASTER TUBES WITH A WATER CURRENT}

We first immersed an $85 \mathrm{~cm}$ long plaster tube that was wider in the center in a water current (Slabe 1995a). Mature networks of scallops formed on the walls of the narrower inflow and outflow sections while pockets formed in the wider inner section. In the sections of rapid change in the size of vortex diameters, the swirling was particularly distinct. The pockets were found throughout the circumference. The hydraulic conditions in the tube are clearly reflected on its circumference. For comparison, as a rule oblong and open scallops formed on plaster blocks immersed in a water current (Slabe 1995b).

In the next experiment we drilled a $12 \mathrm{~mm}$ tube in a plaster block and immersed it in the water current. In 12 hours a funnel-like mouth formed at the inflow side, and after 48 hours the diameter of the entire length of the tube was evenly increased to $35 \mathrm{~mm}$. A mature network of $1.5 \mathrm{~cm}$ long scallops formed throughout the circumference (Fig. 10). Scallops also formed around the inflow mouth indicating the draining of water (Fig. 11a, b, c, d). The scallops are up to $2 \mathrm{~cm}$ long, relatively narrow, and open and often linked in streamlines. A sharp entrance edge gradually occurred at the mouth and almost lost its funnel-like shape (Fig. 11c). Pockets started to form behind the edge in the tube and also in places in front of it (Fig. 11d), which indicates a characteristic swirl zone, which is also typical of the changes in the size of the diameters of cave passages. After four days, a wide (12 cm diameter) and shallow mouth started to develop from the scallops at the beginning of the tube (Fig. 11e). Small tubes also started to form at the contact between two different plasters (Fig. 11a, b, c, d). They are cracklike and branched out as dictated by the contact. The

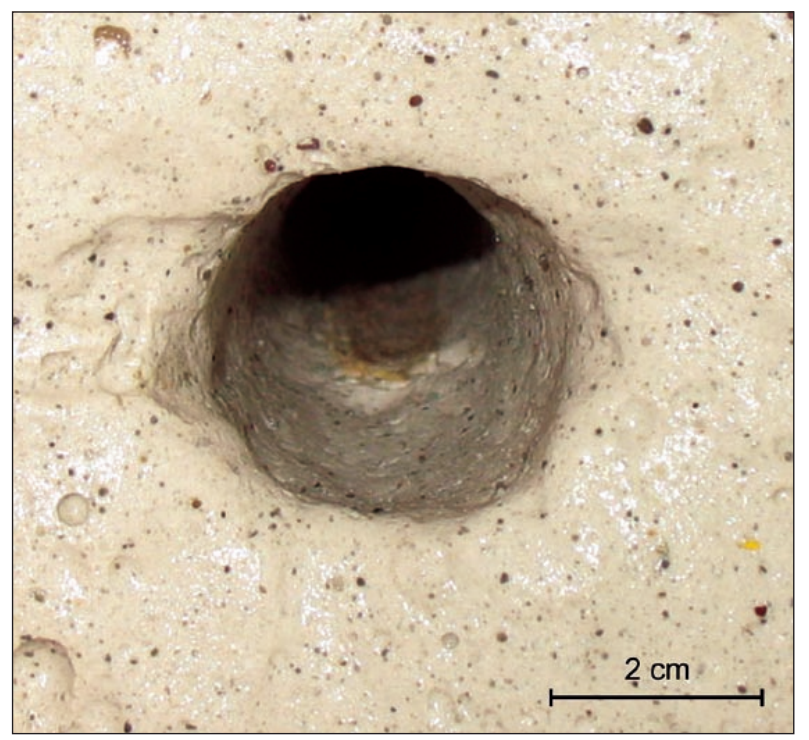

largest have circular cross sections. The more extensive tubes are found in rapidly soluble plaster. In the wider sections, there are large scallops on the circumference, 2 $\mathrm{cm}$ and more in size (Fig. 11c, d, e). The dissection of the system of tubes mainly fosters a variety of swirl and hydraulic conditions that dictate the development of pockets on the circumference. A system of tubes also formed at the contact with the wooden frame that surrounded the model.

In the next experiment we immersed a $73 \mathrm{~cm}$ long plaster tube (Fig. 12) into a water current flowing at 361 $1 / \mathrm{s}$. The narrower inflow section of the tube was $17 \mathrm{~cm}$ in length and $10 \mathrm{~cm}$ in diameter, the outflow section was 21 $\mathrm{cm}$ in length and $5 \mathrm{~cm}$ in diameter, and the diameter of the outflow itself was only $2.5 \mathrm{~cm}$. The diameter of the middle section of the tube was $20 \mathrm{~cm}$. The tube itself was $8 \mathrm{~cm}$ thick. There was a fissure around the circumference of the tube. The tube was left in the water for 55 hours. It was removed several times to check the development of its formation with a special mirror. After 16 hours, scallops were clearly visible on the circumference in the narrower sections of the tube (Fig. 12) and there were shallow pockets at the mouths. The latter also formed on the circumference of the inflow and outflow sections of the tube.

Fig. 10: Tube in plaster of Paris. 

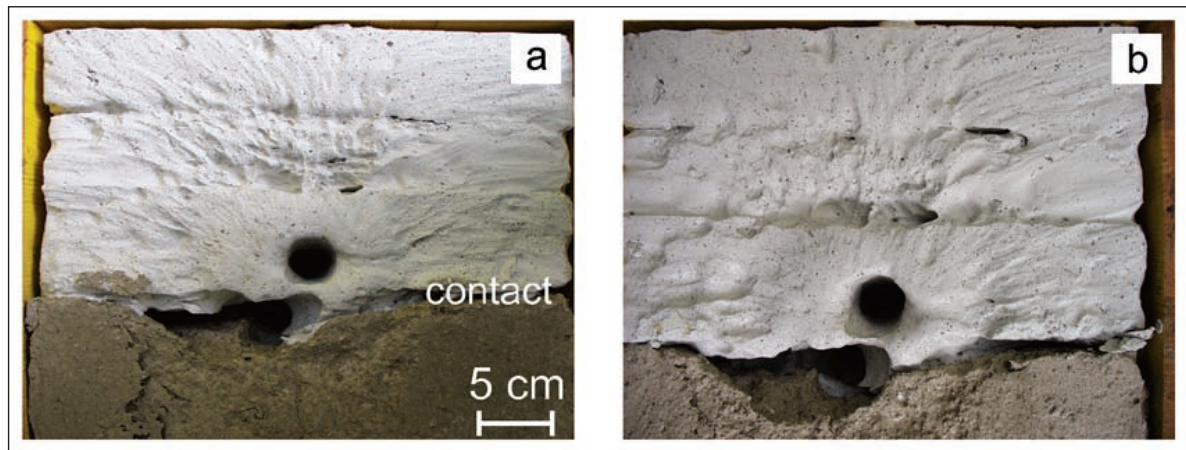

Fig. 11: Development of tube in plaster and at the contact of different plasters.
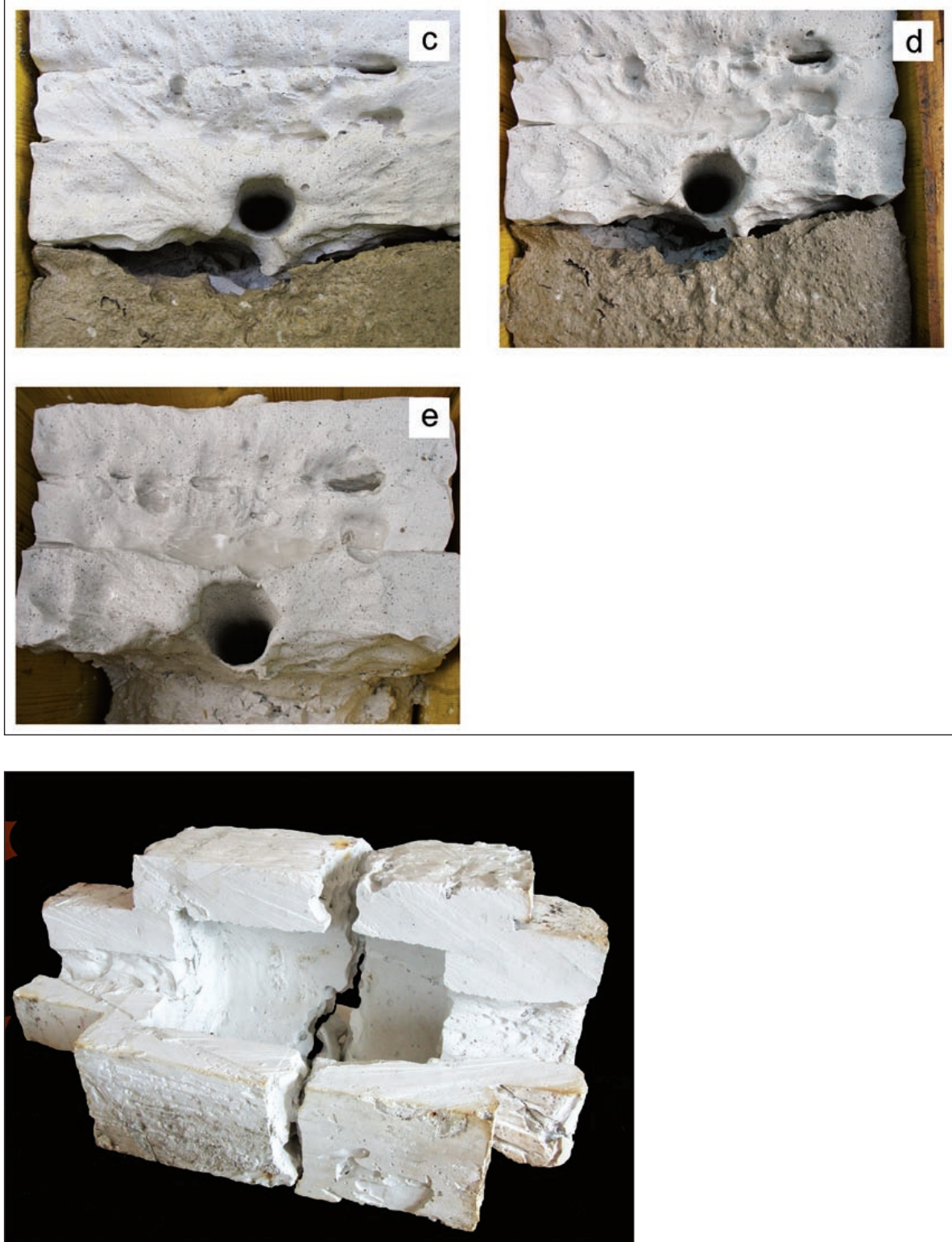

Fig. 12: Plaster tube (60 cm long) with relief. 


\section{ROCK RELIEF IN THE PLASTER TUBE}

The rock relief in the plaster tube reveals the conditions at the termination of the experiment. The diameter of all the sections of the tube had increased on average by $1 \mathrm{~cm}$. Plaster dissolves rapidly and the rock relief changes or adapts to the conditions accordingly. The experiment was terminated when the water widened the fissure in the middle section and began to leak through it substantially.

In the wider inflow section of the tube, the scallops are $2 \mathrm{~cm}$ long (Figs. 12, 13a, b) and in the outflow section, $4 \mathrm{~cm}$ (Figs. 12,13c). These are mature networks of scallops and the scallops are therefore evenly intertwined in the network. The first network (Fig. 13b) still displays a slight elongation of the scallops and openness on the outflow side (Slabe 1995a) but the second network practically neither. The distribution of the first network is more distinctly dictated by obstacles or weak spots in the plaster while the second network is also affected by space since the water swirls evenly throughout the entire cross section, meaning that the swirling action dominates the characteristics of the rock (Slabe 1995b). The walls of the wider section of the plaster tube also display scallop-like forms, particularly individual cups with wedge-shaped runoff tails that indicate the local direction of the water current in this part of the tube. They are oriented toward the widest part of the crack and also lead in that direction from the wall before the narrowing of the tube at the outflow end of the model.

Three types of ceiling pockets can be identified. The first type forms on the circumference of the middle section of the model. They reach $1 \mathrm{~cm}$ in diameter and have a relatively regular semi-circular shape (Fig. 14a, b) while oblong features form only along the most distinct obstacles (non-homogeneous elements, cracks) in the plaster. These features are somewhat larger. Shallow pockets have runoff tails in the direction of the water current. They are a transitional form between scallops and pockets. Their formation and shape is fostered by the emphasized swirling along weak spots in the plaster.
The second type of pocket is linked to the areas of the most distinct swirling near abrupt changes in the diameter of the tube, specifically on the walls after the widening and before the narrowing of the tube. Although most of them are smaller, they can reach $2 \mathrm{~cm}$ in diameter and are semi-circular or oblong in shape. These pockets dominate at the junction of the wall of the widest part of the model and the cross walls after the narrowing and before the widening of the tube. Two circular depressions up to $2 \mathrm{~cm}$ deep formed at these contacts whose walls were dissected by ceiling pockets that as a rule were elongated in the direction of the depression's axis. Some pockets were intertwined.

The largest and most unique pockets formed along the fissure that crossed the center of the model (Fig. 14a, b). They are meandering and cylindrical in shape or resemble slightly narrowing cones with truncated tops. The mouths of the largest pockets reach $3 \mathrm{~cm}$ in diameter. Along the most distinct part of the fissure they lie side by side, merging in a sponge-like perforation of the plaster with a dominant inside to outside direction. Depending on the width and depth of the fissure, such areas could be $10 \mathrm{~cm}$ long and $7 \mathrm{~cm}$ wide. In one spot the water had already removed the plaster, resulting in the formation of an $18 \mathrm{~cm}$ long and $7 \mathrm{~cm}$ wide crack widened in the middle. The sides of the model were enclosed by wood that somewhat blocked the flow of water from the crack. The scallops found at this contact clearly show the direction of the water draining from the crack. There are pockets reaching $4 \mathrm{~cm}$ in diameter on the circumference of the crack.

Pockets and dissected cracks formed over the entire circumference of the tube, including on the floor of the passage as well as on the walls and the ceiling.
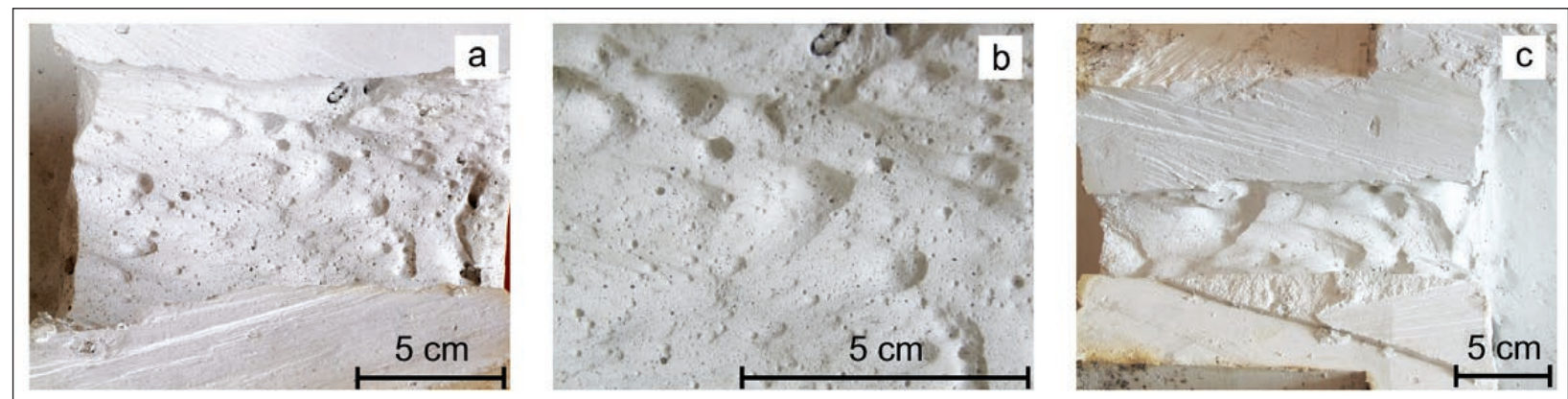

Fig. 13: a small scallops, b. detail of small scallops, c. larger scallops. 


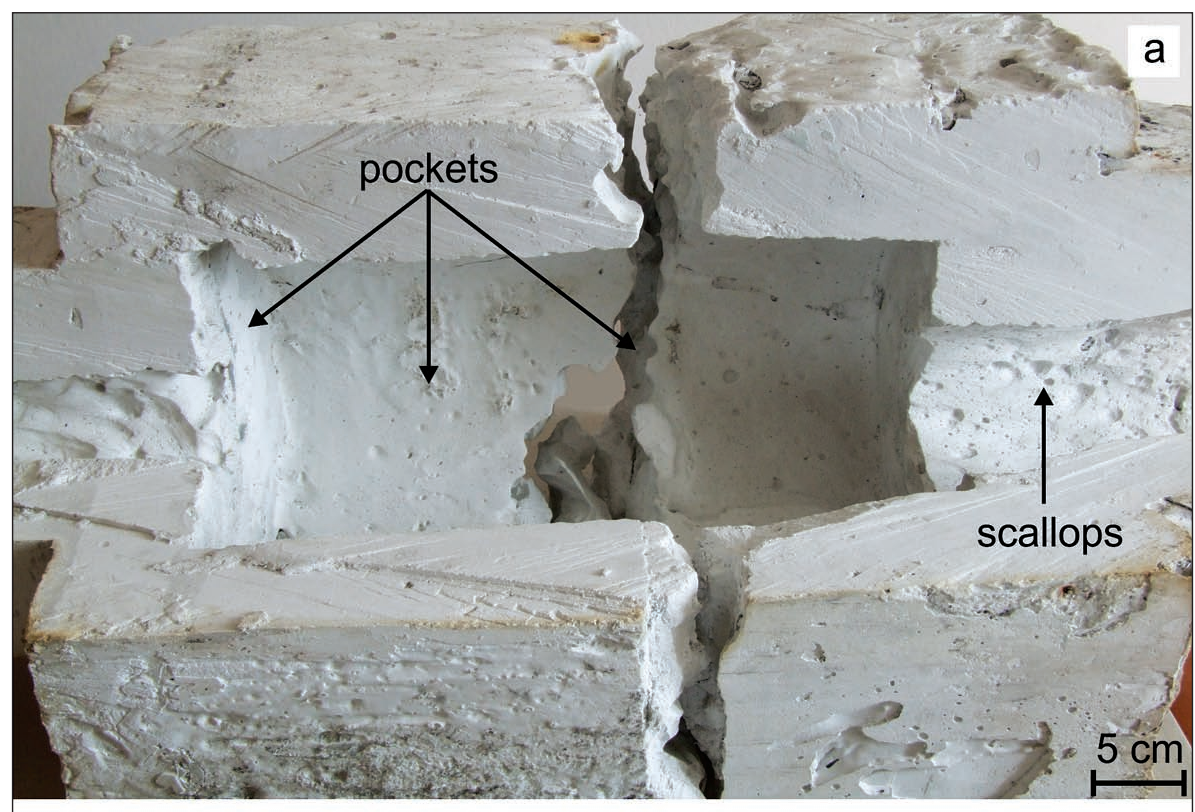

Fig. 14: a. ceiling pocked along fissure, b. small ceiling pockets and scallops.

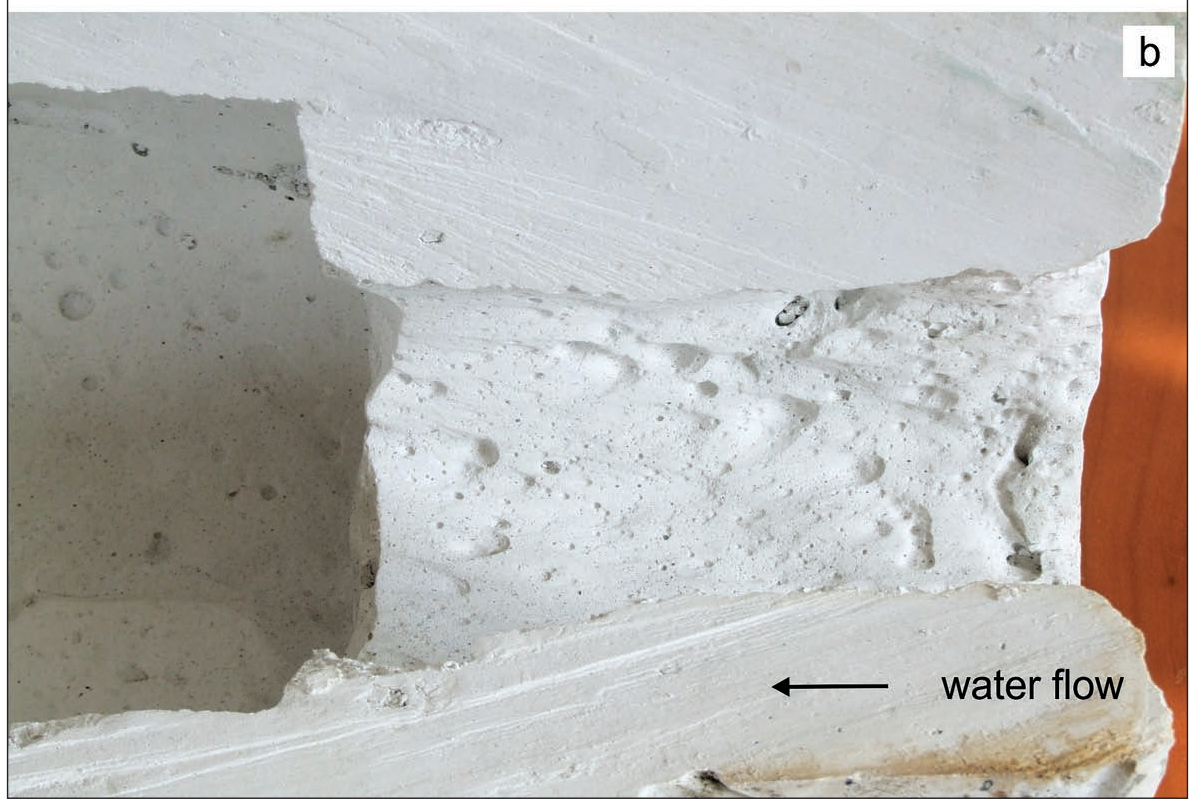

\section{MANNER AND DIRECTION OF WATER FLOW IN A PLASTER TUBE}

The rock relief reflects the final hydraulic situation in the plaster tube. Of course, it is reasonable to conclude that at the beginning of the experiment the water current was faster in the outflow section of the tube and that the scallops on the circumference were smaller and the opposite applied in the inflow section. Detailed monitoring was not possible. Later when the crack along the fissure widened, the water current flowed faster through the inflow part of the tube and the crack, and the current flowed more slowly through the outflow pipe. This is evident from the rock forms in the photographs.
The formation of deep pockets (Fig. 14a, b) along the crack, however, is by far the most telling part of the experiment. Initially, the pockets were narrow and several $\mathrm{cm}$ deep but along the more distinct section of the fissure they grew into domes with pockets on both their tops and their circumferences. This development is characteristic of numerous karst caves. In the model the pockets are found on the entire cross section of the circumference and are wider of course along the more permeable sections of the fissure. The rock relief and the development of the tubes clearly indicate the importance of increased pressure and the widening of the passage along weak spots. Characteristic features form with deep 
domes and pockets. Here we should especially emphasize the comparison with hypogenic caves and advise against hasty explanations that describe the majority of the emphasized forms from longitudinal cross sections of passages as traces of the hypogenic development of caves. The water current swirls over the entire cross section and thus pockets form. The descriptions of pockets in karst caves in most cases present ceiling pockets. They form on the ceilings because water currents typically transport solid material that carves the floor of the passage through erosion or covers it with sediment thus protecting it from corrosion. The origin of pockets whose formation is possibly also influenced by gases in the water and convection due to variations in their level of saturation in the solution is a subject for a future experiment.

\section{DISSOLUTION AND FORMATION OF RELIEF ALONG BEDDING PLANES OF PLASTER AND SIPOREX LAYERS}

\section{PURPOSE OF EXPERIMENT AND DESCRIPTION OF MODEL}

The purpose of the experiment forcing water to percolate between layers of plaster and siporex of varying solubility was to simulate the percolation of water and the formation of relief in natural conditions along bedding planes of homogeneous rock with uniform granulation, along bedding planes of clastic rock containing clasts that dissolve more slowly than the surrounding material, and along bedding planes of rock with a low percentage of soluble carbonate.

The two bottom layers of the stack were siporex (autoclaved aerated concrete) plates used in construction.

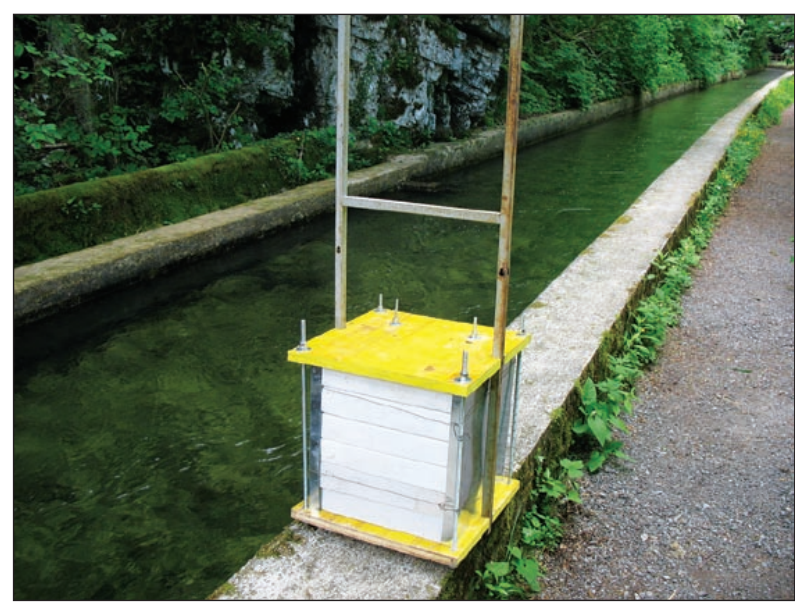

The bottom layer of the two was cracked in the direction of the flow to allow water to enter the material more easily. The middle two layers were composed of pure plaster. The top two layers were composed of two different materials: broken fragments of plaster (with average volumes of a few $\mathrm{cm}^{3}$ ) containing Portland cement added during the mixing for greater hardness (slower solubility) were covered with pure plaster. The lower of the top two layers held plaster fragments containing $5 \%$ Portland cement, and the upper layer, fragments containing $10 \%$ Portland cement (Fig. 15, Tab. 1).

Each layer in the stack was 50 centimeters square and 7.5 centimeters thick.

Fig. 15: Stack with siporex and plaster layers: The bottom two layers are siporex, the middle two layers are pure plaster, the next layer up is plaster with added fragments containing $5 \%$ Portland cement, and the top plaster layer contains added fragments containing $10 \%$ Portland cement.

Tab. 1: Complexometric titration analysis of materials used in the experiment. Composition of layer: 1-plaster, 2-plaster with $5 \%$ Portland cement fragments, 3-plaster with $10 \%$ Portland cement fragments, 4-siporex.

\begin{tabular}{|c|c|c|c|c|c|c|c|}
\hline $\begin{array}{l}\text { Rock } \\
\text { sample }\end{array}$ & $\begin{array}{l}\mathrm{CaO} \\
(\%)\end{array}$ & $\begin{array}{c}M g O \\
(\%)\end{array}$ & $\begin{array}{c}\text { Calcite } \\
\text { (\%) }\end{array}$ & $\begin{array}{c}\text { Dolomite } \\
\text { (\%) }\end{array}$ & $\begin{array}{c}\text { Total carbonate } \\
\text { (\%) }\end{array}$ & $\mathrm{CaO} / \mathrm{MgO}$ & $\begin{array}{c}\text { Insoluble residue } \\
\text { (\%) }\end{array}$ \\
\hline 1 & 10.82 & 1.61 & 15.31 & 7.38 & 22.69 & 6.71 & 84.69 \\
\hline 2 & 15.87 & 1.05 & 25.72 & 4.79 & 30.52 & 15.14 & 74.28 \\
\hline 3 & 20.97 & 1.29 & 34.23 & 5.90 & 40.13 & 16.26 & 65.77 \\
\hline 4 & 16.20 & 0.17 & 28.50 & 0.74 & 29.26 & 95.29 & 70.74 \\
\hline
\end{tabular}



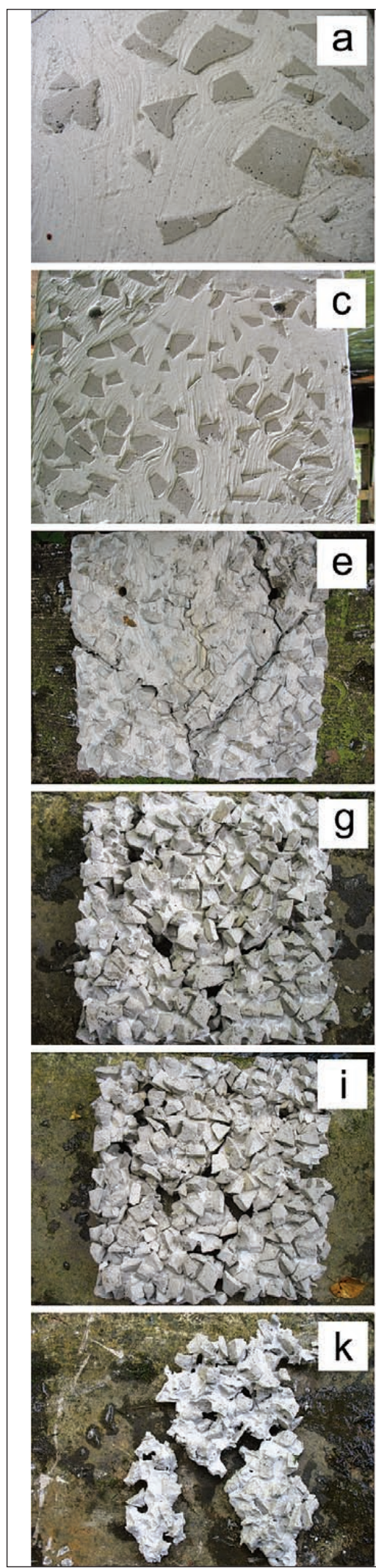

After

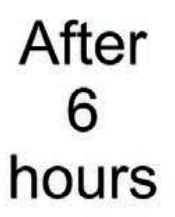

After

48 hours

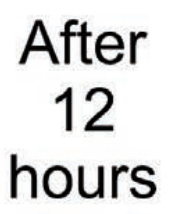

After

24 hours

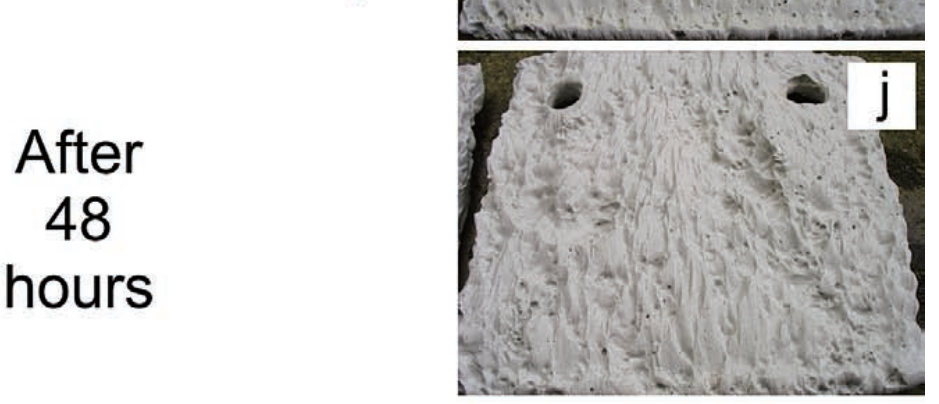

72
hours

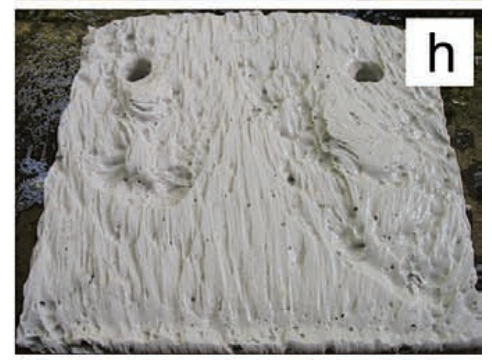

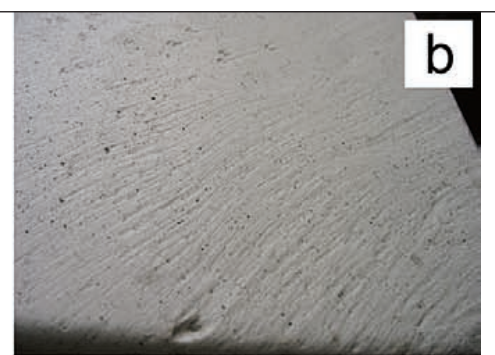
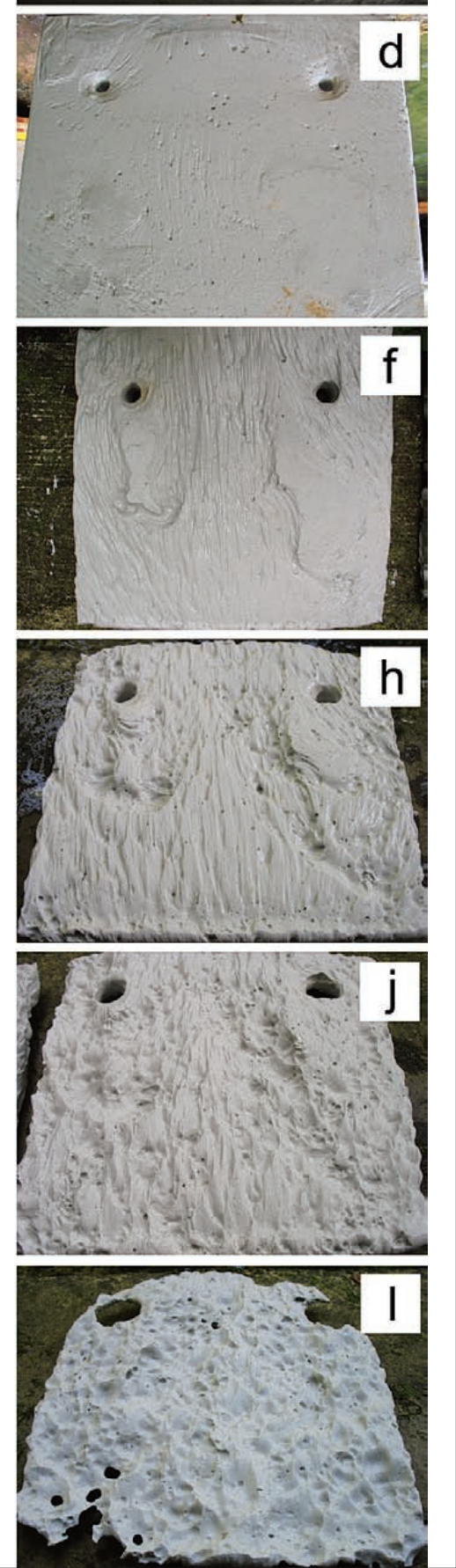

Fig. 16: Development of forms on pure plaster layers (right) and plaster layers with harder fragments (left). Each layer was 50 centimeters square. 


\section{THE COURSE OF THE EXPERIMENT}

The stack of plaster and siporex layers was placed in a flume with a rectangular $1.4 \times 3.4$ meter cross-section. The average level of the water in the flume was $95 \mathrm{~cm}$ with an average discharge of $360 \mathrm{l} / \mathrm{s}$ of the water temperature was $12.4^{\circ} \mathrm{C}$.

The model was first disassembled after three hours. It was evident that the water had begun to intensively dissolve the bedding planes of the upper four layers while the siporex layers showed no changes.

The surfaces of layers containing the more slowly dissolving plaster fragments clearly display mostly one millimeter wide channels that run between the harder plaster fragments. The amount (thickness) of material dissolved is clearly evident along the fragments raised in the relief. It was not possible to identify such differences in the layers made of pure plaster. The slowly dissolving fragments in these layers had a major impact on the erosion of the plaster. On the upstream side of the harder fragments, the plaster was removed more deeply, as it was also at the outer edges and corners of the harder fragments where the velocity of the flow was higher. The channels in the plaster between the harder fragments meander distinctly and the flow of the water has changed direction by up to $90^{\circ}$ (Fig. 16a).

The entire surfaces of the pure plaster layers started to show the formation of predominantly parallel bedding-plane channels a few millimeters wide oriented in the general direction of the water flow in the flume. Plaster contains a small percentage of impuri- ties comprising harder and more slowly soluble grains. Below them, relative to the direction of the flow, channels of even diameter change their morphology. Before the "obstacle" they widen distinctly, and below it they continue in several narrower channels (Fig. 16b). The "obstacles," tiny harder particles, are gradually carried away by the water. The sickle-like notches perpendicular to the water flow seen on the surface most probably develop due to larger harder particles and transform into scallops.

No differences were observed in the dissolving of the harder fragments in either bed. Tiny channels were visible on the surfaces of the harder fragments. In most cases, the diameter of these channels was narrower than that of the channels in the pure plaster-and the direction was mostly parallel to the water flow in the flume.

Six hours after the start of the experiment, the dissolving process was observed on the upstream face of the stack of plaster layers. On the upstream faces of the pure plaster layers, networks of scallops up to several $\mathrm{mm}$ long formed to the left and right in the direction of the water flow, and in the middle of the faces one-millimeter wide and deep cups formed. On the top two layers with the less soluble imbedded fragments, the faces of both layers had places where the water had already reached the harder fragments and the plaster between the fragments had dissolved considerably deeper. The water flowed mainly to the left and right of the model with only a small amount flowing through the fine channels

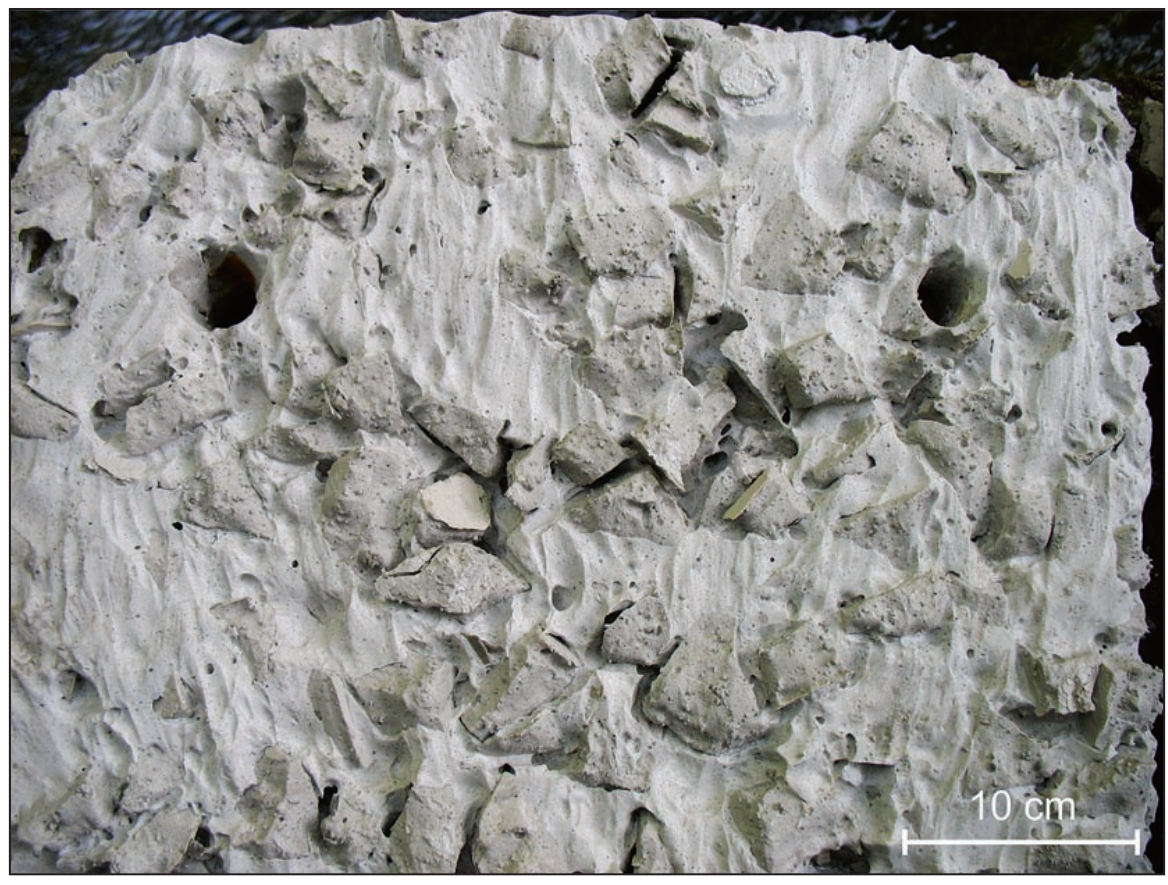

Fig. 17: Channels and pockets in plaster layers with harder fragments. 


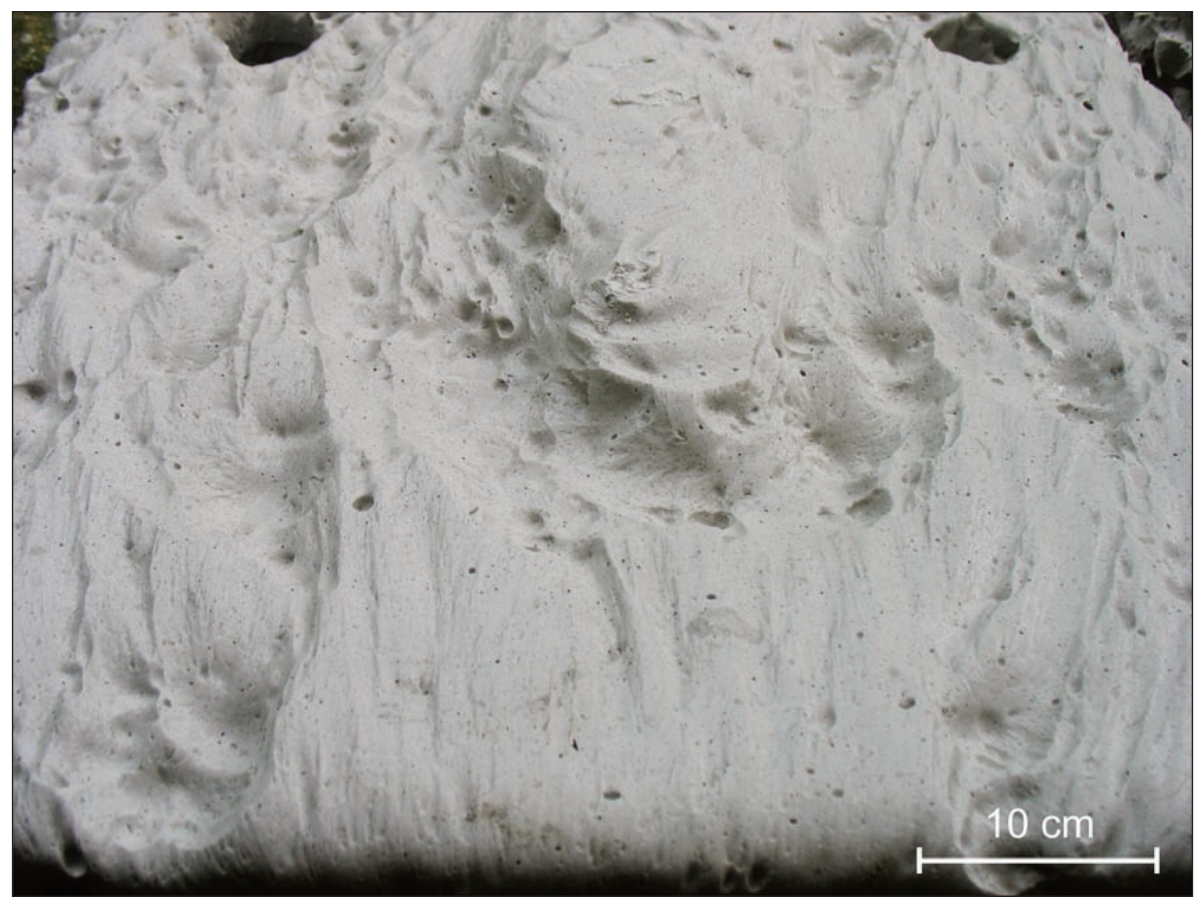

Fig. 18: The turbulent flow of water on pure plaster layers reshaped parallel channels into cups and a network of scallops.

(bedding-plane anastomoses) between the layers, and the direction of the water flow is indicated by the scallops. On the upstream side, the edges have already lost their sharpness, and a major invasion of water between the beds and faster dissolution was expected in the following stages. No changes were observed on the siporex layers.

The channels that had already formed on the surfaces of the layers containing more slowly soluble fragments of plaster started to deepen (Fig. 16c). In the areas where the harder fragments were close together, the flow of water went around them and picked up speed and the channels were deeper, wider, and meandering.

On the surfaces of the layers made of pure plaster, predominantly parallel bedding-plane channels up to a few centimeters wide continued to form in the general direction of the water flow in the flume. The majority of the discharge between two layers flowed down the middle section, while a part wedged out at the edges (Fig. 16d).

The model was again disassembled after twelve hours to observe the dissolving process. The dissolving followed the initial channels observed earlier.

On the upstream faces of the pure plaster layers, scallops continued to develop to the left and right in the direction of the water flow. The faces of the upper two layers containing harder fragments were both dissolved to a great extent around the exposed fragments.

When the model was disassembled, it was established that the water had carved a central stream in the middle section of the upper layer with the harder frag- ments in the direction of the water flow in the flume and had cut through the entire thickness of the layer. The larger stream of water channeled to the areas where the harder, less soluble fragments of plaster were packed together more densely, and where there was less cement between the fragments. The layer began to disintegrate. Simultaneously, due to its faster flow between the layers, in some places the water also started to carve beddingplane channels into the harder fragments of reinforced plaster as well as into the pure plaster. Consistently, the streams no longer avoided the harder fragments as they had at the beginning of the experiment (Fig. 16e). The channels became wider and deeper. The traces of swirling water and more rapid dissolving continued at the contacts between the harder fragments and the pure plaster and where there were clusters of harder fragments.

In pure plaster, the great majority of the beddingplane channels developed over the entire length of the layers; the flow of water between two layers increased its speed, the channels became larger and wider. Only two areas about one square decimeter in size on the left and right side of the layers remained undissolved (Fig. 16f). In front of the still undissolved patches, the water swirled and carved pockets a few centimeters in diameter and up to $1 \mathrm{~cm}$ deep upstream and downstream. While the water entered the entire width of the model in a more or less evenly thick layer, due most probably to the merging of streams between the still undissolved and adjoined parts of the two layers, the water created mostly evenly deep bedding-plane channels at the outflow side of the model. 
No changes were observed on siporex layers.

The model was next disassembled after 24 hours. Even though each plaster layer had dissolved in overall thickness by around $20 \%$ (on the top and bottom of the layers in the direction of the water flow), the model still maintained its original shape. The layer containing plaster fragments reinforced with $10 \%$ Portland cement had dissolved less. A bedding-plane pocket had started to form in the lower of the two siporex layers, and a slight dissolving was noticeable in the area of the crack in the upper siporex layer.

The extensive dissolving of the plaster in the topmost layer with harder fragments continued. In the lower layer with harder fragments, the meandering beddingplane channels generally oriented in the direction of the water flow in the flume and which had also formed on the harder fragments deepened (Fig. 16g). Larger pockets of irregular shapes formed due to the swirling of the water mostly upstream of the harder, less soluble plaster fragments (Fig. 17). In several places, pockets up to a few $\mathrm{cm}$ deep formed in the plaster on the bottom side of the layer.

Where the water entered the model, numerous deeper and shallower bedding-plane channels formed. Due to swirling, the water carved $2 \mathrm{~cm}$ deep and 2 to 3 $\mathrm{cm}$ wide pockets on both layers that merged into channels. Shallower channels also formed alongside the insoluble parts of the plaster.

A chaotic network of somewhat irregularly shaped scallops began to develop to the left and right in the direction of the water flow along the insoluble part. Similar forms occurred at the contact of the layers of pure plaster, but the channels, pockets, and scallops are about $100 \%$ deeper on the upper surface of the lower layer than on the bottom of the upper layer (Fig. 16h).

When the model was inspected after 48 hours, the dissolving of both top and bottom surfaces had made the layers about $50 \%$ thinner. Further minor dissolving was also evident along the crack in the upper siporex layer.
A significant change was observed on the surfaces of the pure plaster layers. To the left and right of the undissolved section of plaster, the water transformed the more or less parallel channels into numerous pockets and a mostly irregular network of scallops due to its completely unhindered flow through the model and strong turbulence (Fig. 18).

A similar development of channels into a network of pockets and scallops due to the largely unobstructed flow of water between two layers was also observed on the inner surfaces between the two layers made of pure plaster (Fig. 16i). Parallel channels transformed into an irregular network of very long and narrow scallops were only preserved in the middle section of these layers.

In the top layer with harder plaster fragments, the water widened the already-carved channel that divided into two legs with a $40^{\circ}$ angle by around $50 \%$ (Fig. 16j). The stream created a new discharge channel and tore a number of the harder plaster fragments from the model at the split section of the entry channel and from several discharge channels and carried them away. The stronger and more turbulent flow deepened the pockets in the plaster, dissolved the contact areas between the harder plaster fragments and plaster even faster, and in most cases rounded the originally sharp edges of the harder fragments.

After 72 hours, the water had almost entirely dissolved the plaster layers. The harder plaster fragments were almost all that was left of the layers containing them (Fig. 16k). The upper of the two layers made of pure plaster was almost completely dissolved, while the siporex layers remained almost unchanged. The water carved a channel along the crack in the upper siporex layer. Only one layer made of pure plaster remained almost whole, although thinned to around $2 \mathrm{~cm}$. All of the original mostly parallel channels had been transformed into a network of pockets and scallops (Fig. 161).

\section{RESULTS AND DISCUSSION}

Plaster models reveal the subsoil shaping of rock and the development of its subsoil rock relief below soil of diverse composition with consequently variously permeable contact and in locally saturated areas of the contact (Figs. 3, 4). Subsoil scallops form over the entire surface when water creeps downward along a permeable contact while subsoil shafts and channels form along less permeable contacts. Longitudinal notches indicate the prevail- ing levels of groundwater while anastomoses occur along horizontal contacts.

The original sloped plaster surface was eroded and the changes of rillenkarren forms were observed (Figs. 5, 6). Rain flutes lengths in the case of water temperature, $45 \pm 5^{\circ} \mathrm{C}$ become longer and faster downwards than water temperature, $24 \pm 3{ }^{\circ} \mathrm{C}$. In the case of water temperature, $45 \pm 5{ }^{\circ} \mathrm{C}$, widths expanded rapidly from 
the beginning time to 100 hours, cross-sections have deep shape from the beginning time to 200 hours. In case of water temperature $24 \pm 3{ }^{\circ} \mathrm{C}$ widths expanded from the beginning time to 350 hours and depths of rain flutes increased rapidly from start to 550 hours.

The rock relief of a plaster tube cave clearly shows its development under different hydraulic conditions. Pockets are found on the entire circumference where larger vortexes form in the water current. Due to the higher water pressure in a tube passage, the water creates distinct notches along areas of weakness in the rock, primarily along fissures and bedding planes where deep domes with pockets form. This is a frequent characteristic in sections of plaster caves with a large inflow and limited outflow of water, although in natural caves, pockets are mostly found on the upper parts of the rock circumference because the floor can be further shaped by material carried or deposited as sediment by the water (Figs. 12, 13, 14). Different networks of scallops are the trace of the characteristics of the rock on which they form and the hydraulic conditions, the velocity of the water current, and the impact of the space on the swirling of the water.
The third model experiment revealed the dissolving and formation of relief on the surface of layers of varying solubility and composition. At the beginning of the experiment, the water dissolved only the faces and outer contacts between the layers. The next stage, with a predominantly laminar and slower flow between layers, saw the formation of longitudinal and meandering anastomosis channels, in some places the origins of a network of scallops, and along the harder, more slowly dissolving fragments, the beginnings of pockets and domes created by swirling water. In the last phase of the experiment, due to the faster and more turbulent flow and swirling along the harder fragments, the water completely transformed the longitudinal and parallel channels into a deep network of pockets, domes, and scallops. Smaller channels developed into larger spaces, and the even swirling of water in the newly formed larger spaces fostered the formation of a network of scallops. Toward the end of the experiment, the scallops started to grow, indicating a gradual slowing of the water flow through the model. With the slow water flow, the small bedding-plane anastomoses grew into a larger channel with wall forms characteristic of a slow water flow.

\section{CONCLUSION}

This type of laboratory modeling has once again proved to be demonstrative and useful for studying karst surfaces and caves. It enables us to deepen our knowledge about the manner of karst formation and its development. It is worth to continue.

\section{ACKNOWLEDGEMENT}

The authors acknowledge the financial support from the Slovenian Research Agency (research core founding P60119-0618).

\section{REFERENCES}

Allen, J.R.L., 1972: The origin of cave flutes and scallops by enlargement of inhomogeneities.- Rassegna speleologica Italiana, 14, 1, 3-20.

Curl, R.L., 1966: Scallops and flutes.- The Transactions of Cave Research Group of GB, 7, 2, 121-160.
Dzulynski, S., Gil, E. \& J. Rudnicki, 1988: Experiments on kluftkarren and related lapis forms.- Z. Geomorph. N. F., 32, 1-16.

Ewers, R.O., 1966: Bedding plane anastomoses and their relation to cavern passages.- Bulletin of the national Speleological Society, 28, 3, 133-141. 
Ewers, R.O., 1972: A model for the development of subsurface drainage routes along bedding planes.- M. Sc. Thesis. University of Cincinnati, pp. 84.

Ewers, R.O., 1982: Cavern Development in the Dimensions of Length and Breadth.- PhD thesis. McMaster University, Hamilton, pp. 398.

Ginés, A., 2009: Karrenfield landscapes and karren landforms.- In: Ginés, A., Knez, M., Slabe, T. \& W. Dreybrodt (eds.) Karst rock features - karren sculpturing. ZRC Publishing, pp. 13-24, Ljubljana.

Glew, J.R. \& D.C. Ford, 1980: A simulation study of the development of rillenkarren.- Earth Surface Processes, 5, 25-36.

Goodchild, J.G. \& D.C. Ford, 1971: Analysis of scallop patterns by simulation under controlled condition.The Journal of Geology, 79, 1, 52-62.

Hada, A., 2008: Formation Processes of Rillenkarren on the Surface of Plaster Block (in Japanese with English Abstract).- Transactions - Japanese Geomorphological Union, 29, 3, 301-311.

Hada, A., 2010: Effects of Temperature on Formative Processes of Rillenkarren on the Surfaces of Plaster Blocks (in Japanese with English Abstract).- Japanese Geomorphological Union, 31, 1, 1-15.

Knez, M., Slabe, T. \& S. Šebela, 2004: Karst uncovered during Bič - Korenitka motorway construction (Dolenjska, Slovenia).- Acta Carsologica, 33, 2, 75-89.

Lange, A., 1959: Introductory notes on the changing geometry of caves structures.-Cave studies, 1-11, 69-90.

Lauritzen, S.E., 1981: Simulation of rock pendants Small scale experiments on plaster models.- In: Beck, B.F. (ed.) Eight international congress of speleology. Georgia Southwestern College, Americus, pp. 407-409, Georgia.

Mowat, G.D., 1962: Progressive changes of shapes by solution in laboratory.- Cave notes, 4/6, 45-49.
Quinif, Y., 1973: Contribution a l'etude morpholoqique des coupoles.- Annales de speleologie, 28, 4, 565-573.

Perne, M. \& F. Gabrovšek, 2009: The problems of rillenkarren development: a modeling Perspective.- In: Ginés, A., Knez, M., Slabe, T. \& W. Dreybrodt (eds.) Karst rock features - karren sculpturing. ZRC Publishing, pp. 55-61, Ljubljana.

Pluhar, A. \& D.C. Ford, 1970: Dolomite karren of the Niagara Escarpment, Ontario, Canada.- Zeitschrift Für Geomorphologie 14, 4, 392-410.

Rudnicki, J., 1960: Experimental work on flutes development.- Speleologia, 2, 1, 17-30.

Slabe, T., 1995a: Cave Rocky Relief and its Speleogenetical Significance.- Zbirka ZRC, 10, ZRC Publishing, pp. 128, Ljubljana.

Slabe, T., 1995b: Experimental modelling of cave rocky relief forms in Paris plaster.- Atti e Memorie della Commissione Grotte E. Boegan, 32, 65-83.

Slabe, T., 2005: Two experimental modelings of karst rock relief in plaster: subcutaneous "rock teeth" and »rock peaks« exposed to rain.- Z. Geomorph. N. F., 49, 107-119.

Slabe, T., 2009: Karren simulation with plaster models.In: Ginés, A., Knez, M., Slabe, T. \& W. Dreybrodt (eds.) Karst rock features - karren sculpturing. ZRC Publishing, pp. 47-54, Ljubljana.

Slabe, T. \& H. Liu, 2009: Significant subsoil rock forms.In: Ginés, A., Knez, M., Slabe, T. \& W. Dreybrodt (eds.) Karst rock features - karren sculpturing. ZRC Publishing, pp. 123-137, Ljubljana.

Trudgil, S., 1985: Limestone geomorphology.- Longman, pp. 196, London.

Tućan, F., 1911: Die Oberflächenformen bei Carbonatgesteinen in Karstgegenden.- Centr. F. Min. Geol. und Paleont., 1911, 343-350. 